$\underline{\text { www.degruyter.com/view/j/arls }}$

\title{
The Analysis of Production and Culling Rate With Regard to the Profitability in a Dairy Herd
}

\author{
József Horváth*, Zsanett Tóth, Edit Mikó \\ University of Szeged, Faculty of Agriculture, Institute of Economics and Rural Development and Institute of \\ Animal Sciences and Wildlife Management, Hungary
}

Accepted June, 2017

\begin{abstract}
As milk prices move away from production costs, dairy farms are under increased pressure to find ways to protect profitability on the farm. Producers have some problems that they can improve. Improve the milk production, produce more milk to sell focused on quality (reduce the amount of high level of somatic cell count). The deterioration of animal health status (lameness, mastitis and different metabolic disorders) can have a serious impact on cow productivity, causing pain and discomfort, production losses and might result in a decision to cull the animal. Improving herd reproductive performance is an important aspect of profitable farm management. The aim of this work is to analyse milk production, reasons of culling and culling rate in different lactation on a dairy cattle farm.
\end{abstract}

Key words: dairy cow economy, culling rate, productive lifetime, break-even point.

\section{Introduction}

In the dairy cattle breeding the longevity of cows and reasons for culling are serious research problems. The profitability of the dairy herd depends on milk the yield of lactation and the productive lifetime of cows. The cows in intensive production systems often do not perform for more than three lactations [1]. The number of days from first calving to culling is the productive lifetime of dairy cow which affects the net returns in dairy production. The average Holstein cow would have about 27 months in milk in her lifetime.

According to Kern et al. (2016) [2] two definitions are used for longevity. The ability to avoid culling for any reason is the true longevity; this is affected by productivity, and functional longevity which is the ability to delay involuntary culling. One of the most important components of the profit from milk production is the high functional longevity which reduces rearing costs and the number of

\footnotetext{
* Corresponding author: József Horváth, horvath@mgk.u-szeged.hu
}

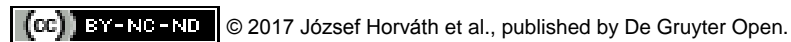
This work was licensed under the Creative Commons Attribution-NonCommercialNoDerivs 3.0 License replacement heifers. Furthermore, it allows cows to achieve maximum milk yield and increases the proportion of higher yielding cows in the herd. [3] Culling of dairy cows is a serious economic decision. [4] Sharifi et al. (2013) analysed 7067 cows' data in Iranian dairy herds. Out of these cows 3904 (56.4\%) were in the first and 3163 $(43.6 \%)$ were in the second lactation. In total, $22.1 \%$ cows were culled; out of these $18.4 \%$ was in first parity and $26.6 \%$ second parity cows. The culling of dairy cows is a serious economic decision. In the authors' opinion low milk yield, lack of conception, availability of replacements, high parity and various health disorders were the frequent reasons for culling.

On other study [5] $9.0 \%$ of tested animals were culled before first lactation and $15.4 \%$ were culled during first lactation for a total culling risk previous to second lactation of $24.4 \%$.

Researchers are trying to improve profitability through selection solutions. Selection for more profitable cows in the United States began with selection improvements in milk protein percentage in dairy cows. Later, traits were combined to form selection indices including yield traits, service sire calving ease, daughter calving ease, daughter 
pregnancy rate, and body conformation, traits. Lifetime profit index includes most of the traits that affect the profitability of a dairy cow [6].

During the past 10 years, measurement of genetic ability of a dairy cow to resist culling is an interesting research topic. These experiments are based on direct analysis of culling information, and indirect analysis using traits correlated with the ability of cows to resist culling [7].

\section{Material and Methods}

In this paper the level of milk production during the lactations and cow culling are examined. Data were gathered in the period 2000-2016 on a dairy cattle farm in South-Hungary.

Analyses over the past seventeen years were evaluated to seek relationships between milk yield and culling rate in a dairy operation. Beyond the calculations, a break-even analysis is also made. Information on the 4845 culling of the cows was used between first and fourth parities in the of cumulative estimation lifetime milk production. Culling rate was analysed between first and more than five lactations of 5727 cases. A general linear regression model was used to evaluate correlation of milk yield and productive lifetime.

The statistical analyses were performed with SPSS22.0 and Excel 2016 software.

\section{Results and Discussions}

The breeding effectiveness and animal welfare of dairy herd are indicated by longevity and lifetime performance traits. They are connected with the profitability of milk production. The high milk yield might cause worsened cow health and fertility and, as a result an increased culling rate. This regrettable situation that has been observed on some Hungarian farms has inspired us to conduct a study on the relationship between some parameters and lifetime performance characteristics (Fig. 1.).

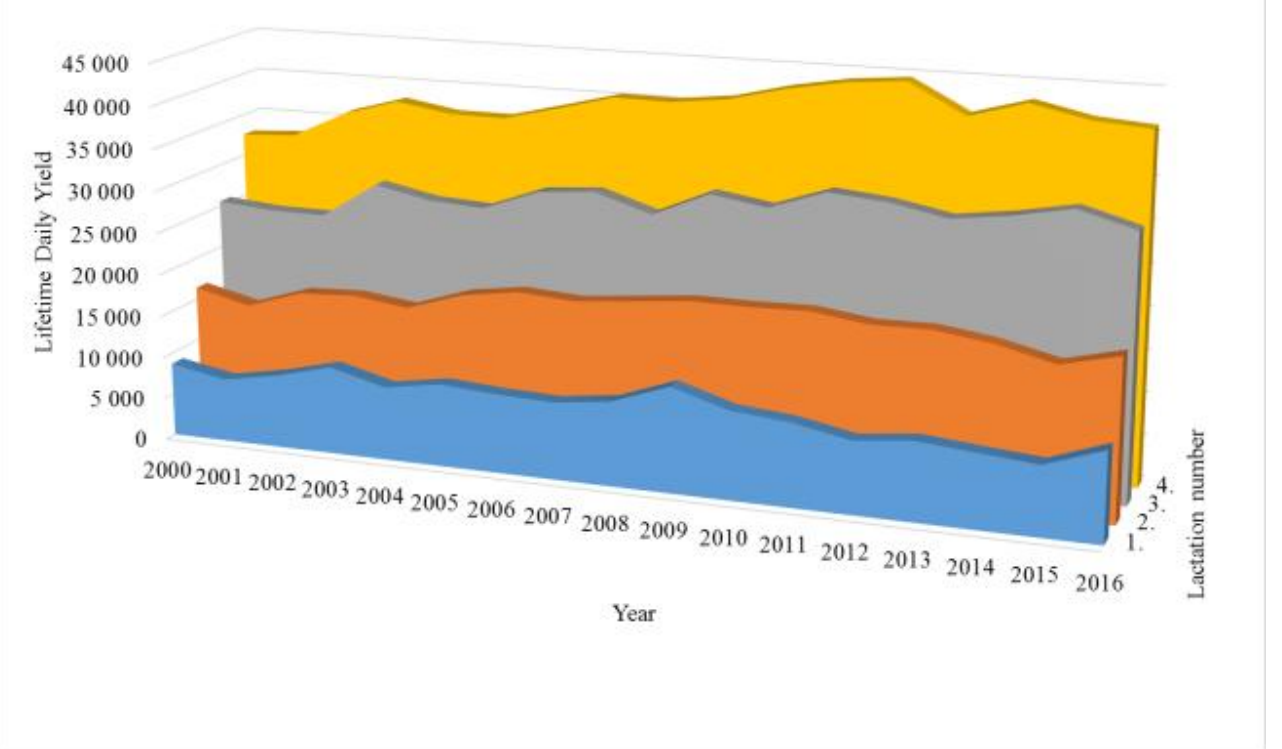

Fig. 1. Cumulated lifetime milk yield of cows examined (in kilogram)

According to our experiences infertility and reproduction problems as well as udder diseases (especially mastitis) and lameness constitute the most frequent reasons for cow culling.

The average milk yield of the examined herd increased from 8145 kilograms to 10247 kilograms between 2000 and 2016. The yearly growth of average production is almost continuous, just 4 of the 16 years show less than $10 \%$ decrease comparing to the previous one.
When the lactation average yields are analysed it can be seen an accelerating increase except the second lactation. In the second lactation the average yield is $3 \%$ less than the first one but the third is $13 \%$ more while the fourth exceeds by $19 \%$ the standardized production. During the examined period the most cows were culled from their first lactation $(26 \%)$ then the rate gradually decreases. Those cows which are in their sixth or posterior lactation represent only $7 \%$ of the total culling number (Fig. 


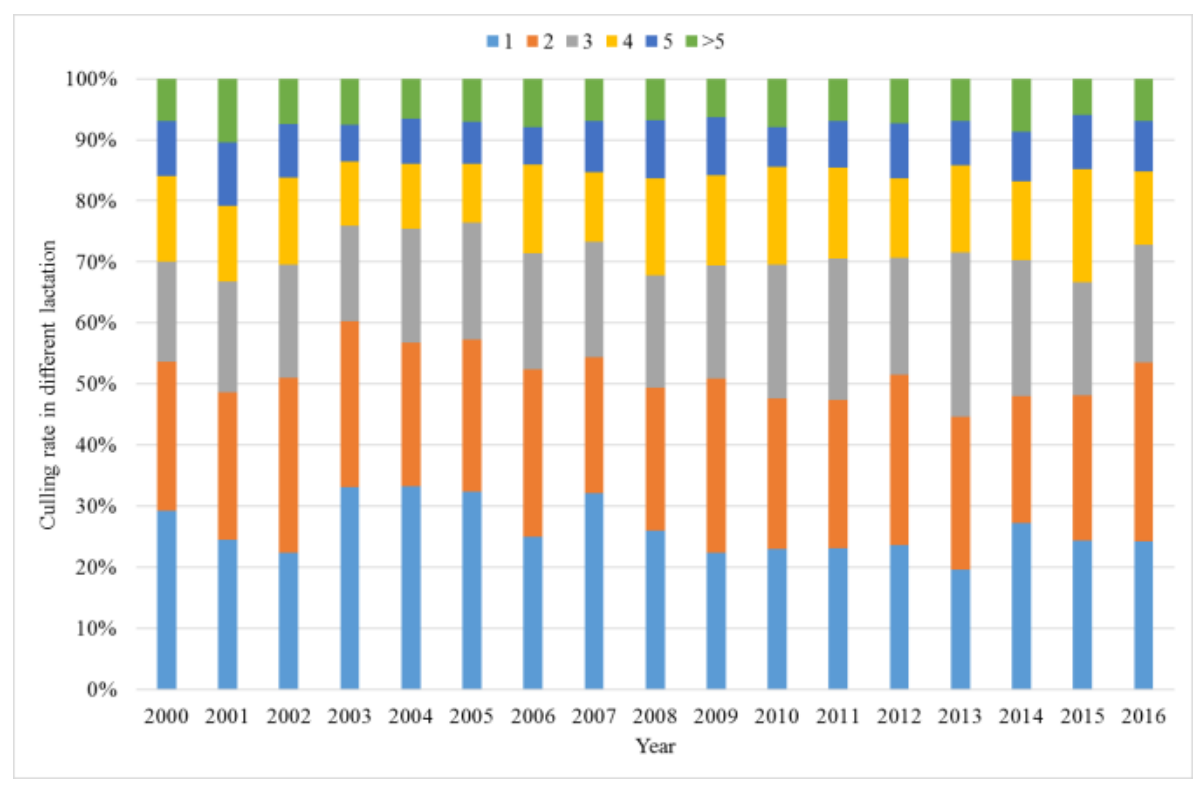

Fig. 2. The culling rate in different lactations of cows examined

Functional longevity can be determined as the number of days from first calving to culling or death, depending on the effect of milk yield [8]. According to the results of Beaudeau et al.(1995) [9] the rate of culling is higher in early and late lactation of older cows, in addition to low producers and cows with poor reproductive performance. Gröhn et al.(1998) [10] did not find any effect of calving season on culling. In addition, Schneider et al.(2007) [11] found that not pregnant cows had a pronounced effect on culling rate: they had a very high risk of being culled in all lactations, especially if they were detected for mastitis in early lactation. According to the data of Neerhof et al.(2000) [12] cow with mastitis had 1.69 times greater risk of being culled than did a healthy herd-mate with all other effects being the same.

When a dairy farm can generate only a moderate profit as well as the economic circumstances do not change so reliably the farmer usually tries to find the break-even point. This point shows the production level at which the revenue exactly covers the production costs. Thus, the production can be considered as profitable exclusively above the break-even point. Regarding the analysed farm the break-even point of milk production was determined by the use of model calculation.

In itself, this calculation is not useful enough for farmers to make an optimal economic decision for individual cows. At the same time, this model provides more information to the decision-making process to avoid serious economic losses. Thus, this model can provide economically optimal guidelines for farmers for cows with various health and fertility disorders.

Table 1

\section{Model calculation of break-even point of milk} production

\begin{tabular}{|l|c|}
\hline \multicolumn{1}{|c|}{ Denomination } & Values \\
\hline Fixed cost/cow (EUR) & 460 \\
\hline Value of by-product/cow (EUR) & 39 \\
\hline Variable cost/kg milk (EUR) & 0.25 \\
\hline Milk producer price/kg (EUR) & 0.3 \\
\hline Break-even point (kg) & 8667 \\
\hline
\end{tabular}

According the calculation shown in Table 1 the break-even point in the case of milk production in general circumstances is 8667 kilograms. It means that this minimum yield should be reached to production costs be exactly covered. The examined farms, except the first and second years, produce more milk in average than the critical level.

It is also important to know how the productive lifetime and the overall milk yield correlate. On the basis of our data analysis it can be stated that all additional day in production result 24 kilograms more milk 


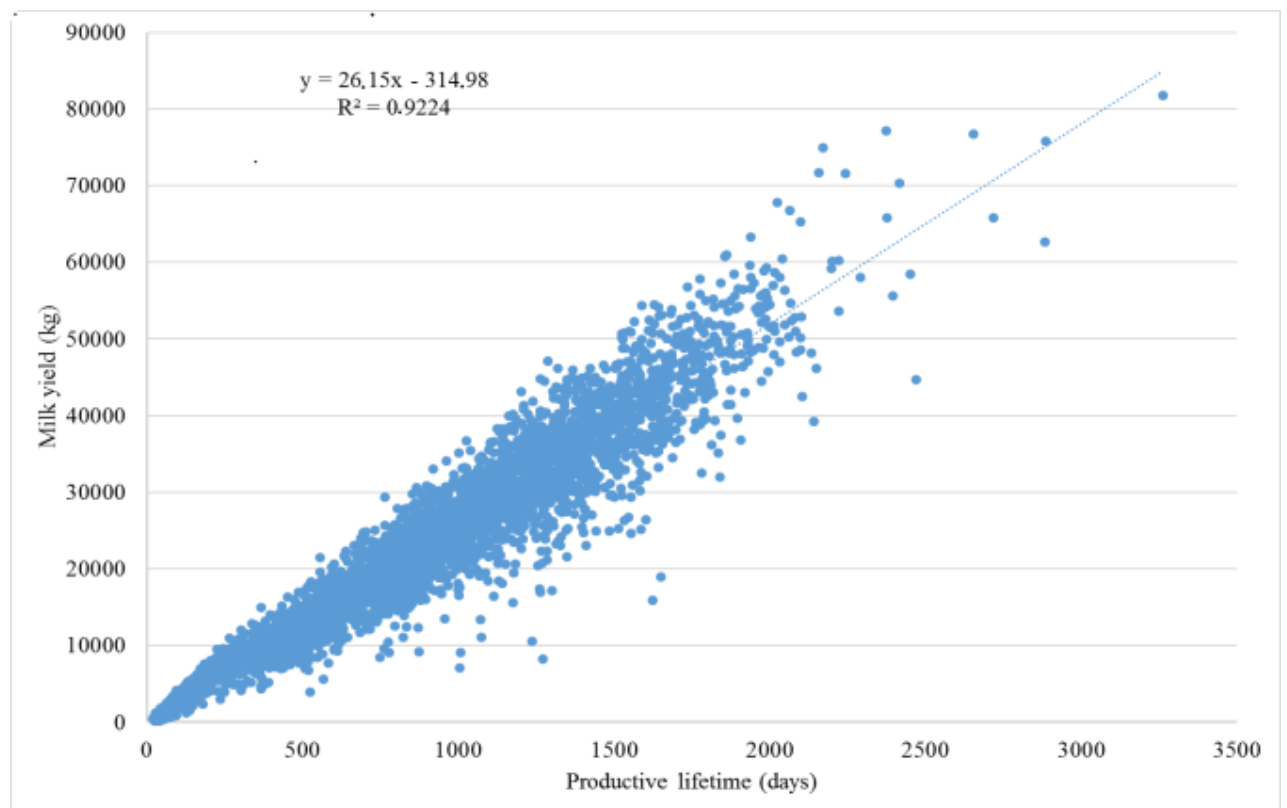

Fig. 3. Correlation between the productive lifetime and the total milk yield

Regression analysis (Fig. 3.) was applied to discover how much milk yield $\mathrm{kg}$ difference is associated with the differences in productive lifetime. The results of the linear regression showed a strong correlation between the productive lifetime and the milk production $\left(R^{2}\right.$ $=0.92)$.

\section{Conclusions}

The high milk production is often associated with unfavourable health and fertility parameters, and as a result with an increased culling rate. Unfortunately mastitis is a costly disease, due to losses of milk production and higher costs (additional inputs to reduce the level of mastitis). In our examination most of the culling was observed during the first and second lactations. There is an intense need to minimize the involuntary culling of cows by providing appropriate feeding and management so that more of cows can be saved in herd, which will in turn facilitate in increasing milk production.

In our study improved longevity resulted in 24 kilograms more milk production per day in the herd. The productivity of the herd also improved due to reducing replacement, reproduction and veterinary costs.

Farmers at first have to cover fixed costs while variable costs also occur. When the producer price of milk is moderate the critical yield appointing the break-even point is relatively high. The farm-level milk yield can principally maximise by keeping the cows in production for a long time.

\section{References}

1. Adamczyk, K., Zaborski, D., Grzesiak, W., Makulska, J. \& Jagusiak, W. (2016). Recognition of culling reasons in Polish dairy cows using data mining methods. Computers and Electronics in Agriculture, 127 , 26-37. https://doi.org/10.1016/j.compag.2016.05.011

2. Kern, E.L., Cobuci, J.A., Costa, C.N. \& Ducrocq, V. (2016). Survival analysis of productive life in Brazilian Holstein using a piecewise Weibull proportional hazard model, Livestock Science, 185, 8996. https://doi.org/10.1016/j.livsci.2016.01.019

3. M'Hamdi, N., Aloulou, R., Bouallegue, M., Brar, S.K. \& Hamouda, M.B. (2010). Study on functional longevity of Tunisian Holstein dairy cattle using a Weibull proportional hazard model, Livestock Science, 132 (1-3), 173-176. https://doi.org/10.1016/j.livsci.2010.05.011

4. Sharifi, H., Kostoulas, P., Bahonar, A., Bokaie, S., Vodjgani, M., Haghdoost, A.A., Karamouzian, M., Foroushani, A.R. \& Leontides, L., Effect of health disorders on the hazard of culling on the first or second lactation in Iranian dairy herds, Preventive Veterinary Medicine, 109 (1-2), 144-147. https://doi.org/10.1016/j.prevetmed.2012.08.017

5. Radke, B.R., Lloyd, J.W., Tempelman, R.J., Kaneene, J.B., Black, J.R. \& Harsh, S. (2000), Parents' predicted transmitting abilities are not associated with culling prior to second lactation of Michigan, USA dairy cows, Preventive Veterinary Medicine, 43 (2), 91-102. https://doi.org/10.1016/S0167-5877(99)00087-2

6. Nayeri, S., Sargolzaei, M., Abo-Ismail, M.K., Miller, S., Schenkel, F., Moore, S.S. \& Stothard, P. (2017). Genome-wide association study for lactation persistency, female fertility, longevity, and lifetime profit index traits in Holstein dairy cattle, Journal of Dairy Science, $\quad 100 \quad$ (2), $1246-1258$.

DOI:http://dx.doi.org/10.3168/jds.2016-11770 
7. Holstein Association USA (2017). Genetic Evaluations for Productive Life, Somatic Cell Score and Net Merit Dollars, from http://www.holsteinusa.com/genetic_evaluations/ss_Ge n_Eval_for_PL.html

8. Sewalem, A., Miglior, F., Kistemaker, G.J., Sullivan, P. \& Van Doormaal, B.J. (2008), Relationship between reproduction traits and functional longevity in Canadian Dairy Cattle, Journal of Dairy Science, 91 (4), 1660-1668. DOI:10.3168/jds.20070178

9. Beaudeau, F., Ducrocq, V., Fourichon, C. \& Seegers, H. (1995). Effect of disease on length of productive life of French Holstein dairy cows assessed by survival analysis, Journal of Dairy Science, 78 (1), 103-117. DOI:10.3168/jds.S0022-0302(95)76621-8

10. Gröhn, Y.T., Eicker, S.W., Ducrocq, V. \& Hertl, J.A. (1998). Effect of diseases on the culling of Holstein
Dairy Cows in New York State, Journal of Dairy Science, 81 (4), 966-978. DOI:10.3168/jds.S00220302(98)75657-7

11. Schneider, M.P., Strandberg, E., Emanuelson, U., Grandinson, K. \& Roth, A. (2007), The effect of veterinary-treated clinical mastitis and pregnancy status on Culling in Swedish Dairy Cows, Preventive Veterinary Medicine, $80 \quad$ (2-3), 179-192. https://doi.org/10.1016/j.prevetmed.2007.02.006

12. Neerhof, H.J., Madsen, P., Ducrocq, V., Vollema, A.R., Jensen, J. \& Korsgaard, I.R. (2000). Relationships between Mastitis and Functional Longevity in Danish Black and White Dairy Cattle Estimated Using Survival Analysis, Journal of Dairy Science, 83 (5), 1064-1071. DOI:10.3168/jds.S00220302(00)74970-8. 